\title{
LexCult
}

| ARTIGOS

DOI: https://doi.org/10.30749/2594-8261.v4n2p288-314

\section{COMPETÊNCIAS, ORGANIZAÇÃO E ATUAÇÃO DA JUSTIÇA FEDERAL, NO DISTRITO FEDERAL, DURANTE O PERÍODO DE 1890 A 1937}

\section{COMPETENCES, ORGANIZATION AND OPERATION OF FEDERAL JUSTICE, IN THE FEDERAL DISTRICT, DURING THE PERIOD FROM 1890 TO 1937}

\section{Ronald Krüger Rodor}

Resumo: O presente artigo tem por objetivo descrever como foi organizada e como se desenvolveu a Justiça Federal na capital da República durante o período de 1890 a 1937, com enfoque especial no tipo de demanda que concretamente esteve submetida à jurisdição daquela instituição, a partir da análise da indexação de processos do acervo histórico da Seção Judiciária do Rio de Janeiro e do exame das notícias de periódicos da época que noticiavam assuntos relacionados ao Judiciário da União.

Palavras-Chave: História. Justiça Federal. Competências. Organização.

Abstract: The present article aims to describe how the Federal Justice was organized and developed in the capital Republic during the period from 1890 to 1937, with a special focus on the type of lawsuit that was concretely submitted to the jurisdiction of that institution, from the analysis of the indexation of historical processes of the Judicial Section of Rio de Janeiro, and by examining the news of periodicals of the time that reported matters related to the Federal Judiciary.

Keywords: History. Federal Justice. Jurisdiction. Organization.

Recebido em: 30/07/2020

Aceito em: 03/09/2020

\footnotetext{
"Juiz Federal na Seção Judiciária do Espírito Santo. Mestre em Direito do Programa de Pós-Graduação em Direito Processual da Universidade Federal do Espírito Santo - UFES. E-mail: rodor2014@gmail.com.
} 


\section{INTRODUÇÃO}

Com a proclamação da República, em 1889, o Brasil, além da mudança na forma de governo, também fez a opção pela forma federativa de estado, elevando à categoria de estados federados as antigas províncias do Império.

Ainda durante o Governo Provisório, em outubro de 1890, foi estabelecida, também, a criação da Justiça Federal brasileira, antecipando-se, assim, às discussões sobre o modelo constitucional a ser adotado para o Poder Judiciário nacional durante a Assembleia Constituinte de 1891.

De 1890, quando estabelecida no plano formal, até 1937, quando extinta a Justiça Federal brasileira em seu primeiro ciclo de funcionamento, referida instituição foi objeto de inúmeras e diferentes normatizações, assim como esteve no centro das principais questões jurídicas debatidas no país, incluindo o desenvolvimento da doutrina brasileira do habeas corpus.

Destaque especial teve a Justiça Federal do Distrito Federal, única seção judiciária do país a contar com três varas federais no período, local onde estava situado o único tribunal responsável pelo julgamento dos recursos oriundos de todos os juízos federais do país, e sede dos poderes políticos nacionais, o que naturalmente acarretou a submissão à jurisdição das varas federais da capital da República de algumas das mais importantes ações judiciais da Primeira República.

No presente artigo mostraremos como foi a criação, organização e o desenvolvimento da Justiça Federal no Distrito Federal, no período de 1890 a 1937, com especial enfoque no tipo de demanda que concretamente esteve sob sua tutela, a partir da análise de textos de periódicos da época e, principalmente, da indexação dos processos do acervo histórico da atual Seção Judiciária do Rio de Janeiro - SJRJ.

\section{DEBATES FEDERALISTAS E A ADOÇÃO DA DUALIDADE DE JURISDIÇÃO NO BRASIL}

Historicamente, as discussões sobre a adoção do republicanismo no Brasil Império estiveram de certa forma vinculadas às questões sobre a maior autonomia das províncias e mesmo sobre a implantação do Estado Federal. 
Claro que os conceitos de republicanismo e federalismo não se confundem. Durante o séc. XIX, uns dos principais defensores do federalismo no Brasil, Aureliano Cândido Tavares Bastos (1870, p. 403-404), ao tempo em que defendia a maior autonomia das províncias, se colocava a favor da monarquia, propugnando que dela deveria partir a iniciativa de descentralização política.

O movimento republicano brasileiro, no entanto, soube detectar que boa parte da insatisfação existente com a monarquia nacional decorria não da inexistência dos mecanismos próprios do republicanismo, como a eletividade dos representantes políticos e a alternância no exercício do poder, mas sim, da forte centralização política do Segundo Reinado, tanto que, no famoso Manifesto Republicano, publicado no jornal A República, de 3 de dezembro de 1870, o que vemos é um texto em grande parte federalista, nele estando expresso que "[...] a autonomia das províncias é, pois, para nós mais do que um interesse imposto pela solidariedade dos direitos e das relações provinciais, é um princípio cardeal e solene que inscrevemos em nossa bandeira". (MANIFESTO, 1939).

No Congresso Constituinte, em fins de 1890 e princípios de 1891, já não restavam dúvidas de qual o modelo de estado que deveria ser adotado. Os discursos parlamentares praticamente fundiam os princípios republicanos e federalistas num só molde, de modo que não parecia haver alternativa sem a adoção conjunta de República e Federação. Para o deputado José Luís de Almeida Nogueira, discursando em sessão de 2 de janeiro de 1891, durante a $22^{a}$ sessão da Constituinte, "a federação monarquista seria apenas um estágio intermediário do caráter evolutivo de Estado nacional, onde a República Federativa constituiria seu ápice". (BRASIL, 1926, p. 36).

Mas, se o estado federal já era dado como de adoção incontornável, poderse-ia dizer o mesmo em relação à dualidade de jurisdição?

A dualidade de jurisdição, ou seja, a adoção de uma Justiça Federal ao lado dos organismos judiciários dos estados federados, embora seja o modelo mais comumente adotado nos diferentes tipos de estado federal, não necessariamente é o único possível.

Vera Lúcia R. S. Jucovsky (2003), em estudo para o Conselho da Justiça Federal - CJF, em 1997, demonstrou que na maioria das nações de modelo federal por ela analisados, Estados Unidos, México, Alemanha e Argentina, adotou-se sistema semelhante ao brasileiro, com jurisdições estaduais e federal. A Suíça seria 
uma exceção, pois sua dualidade jurisdicional é parcial, existindo apenas tribunais federais, mas não juízos de primeiro grau.

A par desses casos estudados por Jucovsky, no entanto, existem inúmeros outros. Com efeito, a Austrália também segue modelo de jurisdição dual parcial, com cortes judiciais federais apenas no segundo grau (RODOR, 2020, p. 36), ao passo que na Federação Russa a jurisdição é una, nacional, ainda que existentes diversos órgãos jurisdicionais (juízes de jurisdição ordinária, tribunais regionais federais, tribunais superiores das repúblicas, territórios, regiões ou assemelhados e Supremo Tribunal da Federação Russa).

E não são apenas os modelos atuais que desmentem a imposição da dualidade jurisdicional no estado federal. Com efeito, já no século XIX, os modelos suíço e venezuelano, de 1874 e 1891 respectivamente, diferiam do norte-americano e do argentino, que serviram de inspiração principal para o Brasil (OTÁVIO, 1897). Deve-se lembrar, também, que a experiência brasileira pretérita era de jurisdição una, pois assim funcionou o Poder Judicial do Império.

Havia dúvidas, portanto, quanto à adoção da dualidade jurisdicional. Tanto que algumas das propostas individuais dos membros da chamada Comissão dos Cinco, responsável por elaborar o anteprojeto de texto constitucional, previam o modelo de jurisdição una, como aqueles apresentados por Américo Brasiliense e por Magalhães de Castro. (KOERNER, 2010, p. 153-154).

O anteprojeto consolidado da Comissão dos Cinco, no entanto, assim, como seu texto revisado pela comissão de ministros do Governo Provisório, onde se destacaram Rui Barbosa e Campos Sales, acabaram por estabelecer a dualidade jurisdicional, sendo ela prevista no Decreto n. 510, de 22 de junho de 1890 (BRASIL,1890a), contendo o texto que seria debatido no Congresso Constituinte.

Se para Rui Barbosa (1943, p. 330) a Justiça Federal era "a garantia da legalidade constitucional, a força de equilíbrio entre os estados e o Estado, o grande elo da República", para Campos Salles era necessário consagrar a possibilidade de os estados terem suas próprias estruturas judiciárias, aprofundando, assim, o caráter federativo da nação, ou, como se expressou matreiramente na exposição de motivos do Decreto n. 848, instituidor da Justiça Federal, o organismo judiciário, no sistema federativo, "[...] repousa essencialmente sobre a existência de duas soberanias na tríplice esfera de poder público". (SALLES apud BASTOS, 1913, p. 2). 
Não foi sem objeções, no entanto, que a dualidade jurisdicional restou consagrada na Carta da República de 1891. Nos debates do Congresso Constituinte, parlamentares como Amphilophio Botelho Freire de Carvalho, futuro ministro do STF, trataram de contraditar os argumentos de Campos Sales, enquanto ministro da Justiça, pela necessidade de existirem estruturas judiciárias estaduais. Amphilophio indagou, retoricamente, em sessão de 2 de janeiro de 1891, se não poderia ser federal toda a magistratura do país (BRASIL, 1926, p. 69-70). A tese unitarista, é bom lembrar, chegou a ser acatada, numa primeira votação, pela Comissão dos 21, responsável por elaborar o parecer geral acerca do projeto de Constituição do Governo Provisório (KOERNER, 2010, p. 162), mas acabou restando vencida.

Agenor de Roure (1979, p. 23), alude que no decorrer dos debates na Constituinte, os magistrados do país também eram em sua maioria contrários à dualidade, mas Campos Sales e Augusto de Freitas defenderam-na arduamente, restando consagrada, no art. 63 da primeira Carta Magna republicana, a ampla liberdade para que os estados se organizassem, apenas devendo respeitar os princípios constitucionais.

No plano doutrinário, vários comentaristas da Constituição da República de 1891 se mostraram favoráveis à dualidade, como João Barbalho (1924, p. 296), para quem o sistema republicano federal era por essência dualista, Amaro Cavalcanti (1900, p. 203), para quem à fórmula federativa adotada no Brasil mostrava-se adequada a existência da jurisdição dual, e Pedro Lessa (1915, p. 4), que afirmava que "à organização constitucional federativa tem sido sempre inerente a dualidade da justiça". Em contrapartida, houve quem criticou acidamente o aproveitamento dos magistrados do Império na nova organização do Poder Judiciário, em especial na composição do STF, feita com os conselheiros do antigo Supremo Tribunal de Justiça. (FREIRE, 1894, p. 182-183).

\section{ORGANIZAÇÃO, ESTRUTURAÇÃO E COMPETÊNCIAS DA JUSTIÇA FEDERAL ATÉ 1937}

A criação formal da Justiça Federal brasileira deu-se antes mesmo do estabelecimento do novo regime constitucional em 1891. Com efeito, já em outubro de 1890, o Governo Provisório editou o Decreto n. 848, prevendo que a instituição seria organizada em duas instâncias, a primeira composta de juízes de seção e 
substitutos e a segunda de um único tribunal, o Supremo Tribunal Federal. (BRASIL, 1890c).

A Constituição de 1891 (BRASIL, 1891a), posteriormente, estabeleceu em seu art. 55 que o Poder Judiciário da União seria composto pelo STF e por juízes e tribunais federais, distribuídos pelo país, tantos quantos o Congresso viesse a criar.

Assim, a par das seções judiciárias criadas em cada estado e no Distrito Federal, passou a ser possível a criação de tribunais federais, o que chegou realmente a ser determinado por meio do Decreto n. 4.381/1921 (BRASIL, 1921), mas jamais implementado de fato. A dificuldade prática para a criação desses tribunais era a própria interpretação dada pelo STF ao dispositivo constitucional, posto que, cabendo à Corte Suprema julgar os recursos contra as sentenças dos juízes federais, a expressão "tribunais federais" era entendida como sendo apenas juízos coletivos de primeiro grau.

A Constituição da República de 1934 tentou resolver a questão determinando a criação de um novo tribunal federal, especificamente para o julgamento das apelações e recursos da Justiça Federal de primeira instância, desde que não envolvessem matéria constitucional (art. 79) (BRASIL, 1934). Não obstante, a breve vigência desta Constituição não permitiu que o dispositivo constitucional chegasse a ser regulamentado. Somente com a Constituição Federal de 1946 (BRASIL, 1946), criando o Tribunal Federal de Recursos - TFR, o problema foi solucionado, mas em momento no qual a Justiça Federal de primeira instância já não mais existia, extinta que havia sido pela Constituição da República de 1937 (BRASIL, 1937), sendo os feitos federais processados, no primeiro grau, em varas especializadas das Justiças dos estados.

O STF foi, assim, até 1937, o tribunal de apelações da Justiça Federal, a par de instância extraordinária em questões constitucionais e de direito federal quando as decisões das Justiças dos estados considerassem válidos atos dos governos estaduais ou leis locais em face da Constituição da República ou das leis federais (art. 59, $\$ 1^{\circ}, b$, da CR/1891) (BRASIL, 1891a). Interessante notar que a Emenda Constitucional de 1926 (BRASIL, 1926), única alteração sofrida pelo texto constitucional de 1891, suprimiu essa competência extraordinária, ficando mantido apenas o acesso à Corte Suprema nos casos específicos previstos em seu art. 61 (processos de habeas corpus e de espólio de estrangeiro, estes últimos quando não 
previstos em tratado ou convenção internacionais). A Carta constitucional de 1934 (BRASIL, 1934), no entanto, restabeleceu a competência extraordinária do STF nas causas vindas das Justiças estaduais em seu art. 76, III, acabando até mesmo por aumentar as hipóteses de cabimento de recurso.

De qualquer modo, parece que a partir, principalmente, dos anos 1920 a Corte Suprema tinha muitas dificuldades de cumprir seu duplo papel, o que acarretou algumas tímidas iniciativas no sentido de se criar uma alçada para os recursos ordinários com origem na Justiça Federal. O próprio citado Decreto n. 4.381/1921 (BRASIL, 1921) tratou de estabelecer em seu art. 1ำ que a alçada dos juízes federais seria de 5:000\$ (cinco contos de réis ou cinco milhões de réis), o que não parece ter sido suficiente para reduzir de forma substancial o número de recursos que chegavam ao STF. Esta, aliás, era uma das mais comuns reclamações em relação ao funcionamento do Judiciário da União, consoante as severas críticas feitas pelo ministro Arthur Ribeiro ao defender, na Assembleia Constituinte de 1933, a revisão do sistema dual de jurisdição (BRASIL, 1936, p. 368-369), posição, no entanto, que restou vencida graças a defesa intransigente daquele por parlamentares constituintes como Levi Carneiro (1916, p. 7), que em obra publicada muitos anos antes já chamava a atenção para a pouca importância que se dava à organização do STF.

Quanto à Justiça Federal de primeiro grau, afora algumas pontuais ampliações de sua estrutura, como a criação de uma segunda vara nas seções judiciárias do Distrito Federal, esta pelo Decreto n. 1.152/1904 (BRASIL, 1904a), de São Paulo e Minas Gerais, ambas pelo Decreto n. 4.848/1924 (BRASIL, 1924c), e a criação da terceira vara federal do Distrito Federal, também pelo Decreto n. 4.848, a principal e mais importante alteração na estrutura da instituição foi a criação do cargo de juiz suplente de substituto pela Lei n. 221/1894. (BRASIL, 1894).

Figura bastante controvertida, os juízes suplentes exerciam mandatos temporários de quatro anos e, apesar de inicialmente serem indicados pelos juízes seccionais, esse filtro logo foi suprimido pelo Decreto n. 967/1903 (BRASIL, 1903). Esse diploma legislativo também alterou a jurisdição territorial desses magistrados, que deixaram de seguir as circunscrições estabelecidas em decretos federais para serem fixados em número de três para cada comarca em que se dividisse a unidade federativa estadual. Para alguns, esses magistrados leigos constituíram o principal ponto de interferência das forças políticas locais na magistratura federal (FREITAS, 
2003, p. 34), sendo em sua grande maioria incapacitados para o exercício de suas funções de preparo e auxílio (BASTOS, 1912, p. 18), não contando os juízes seccionais, ademais, de instrumentos eficientes para exercerem o controle desses auxiliares. (KOERNER, 2010, p. 193).

Da mesma forma que seus suplentes, os juízes federais substitutos ocupavam também mandatos temporários, só que de seis anos ao invés de quatro. Por outro lado, embora o Decreto n. 848/1890 (BRASIL, 1890c) previsse para eles apenas funções de substituição, para casos de afastamento dos seccionais, já a partir do Decreto n. 1.420-A/1891 (BRASIL, 1981b) eles passaram a ter funções de preparação dos feitos, passando a exercer funções típicas de auxílio, o que foi confirmado pelo art. 18 da Lei n. 221/1894 (BRASIL, 1894). Mais do que isso, não havia vedação legal às sucessivas reconduções, de modo que não foram raros casos em que juízes federais substitutos ficaram por décadas no exercício da função, caso de Celestino Carlos Wanderley, juiz federal substituto na Seção Judiciária do Rio Grande do Norte de 1903 a 1937.

Evidentemente, o sistema de garantias da magistratura, previsto na Constituição da República de 1891 (BRASIL, 1891a), era direcionado aos juízes seccionais e ministros do STF (art. 57), pois somente eles poderiam ser dotados de vitaliciedade. Aos juízes temporários, substitutos e suplentes, não seria possível estender tal prerrogativa. À vitaliciedade o Decreto n. 848 acrescentava, em seu art. $2^{\circ}$, a inamovibilidade dos juízes seccionais, uma vez que tal garantia somente restou inserida no texto constitucional com a Emenda de 1926, essencialmente para assegurá-la aos juízes estaduais, constantemente vítimas de abusos dos Executivos nos estados. (NEQUETE, 2000, p. 47).

No que tange às competências da Justiça Federal, muitas das que Ihe foram atribuídas pela Constituição da República de 1891 eram semelhantes àquelas posteriormente previstas no Ato Institucional n.. 2/1965 (BRASIL, 1965), diploma que recriou tal instituição após o período de extinção de 1937-1965, ou ainda as que foram estabelecidas na Constituição Federal de 1967 (BRASIL, 1967), ou na Emenda Constitucional n. 1/1969 (BRASIL, 1969). Dentre as mais óbvias estava a regra de competência cível geral, abrangente das causas que tinham a União como assistente, opoente, autora ou ré. As questões de direito marítimo e navegação também estavam elencadas no rol de competências da Justiça Federal, o que só deixou de ser de sua 
alçada com a Emenda Constitucional n. 7/1977 (BRASIL, 1977), mantidos apenas o processamento e julgamento dos crimes cometidos a bordo de embarcações ou aeronaves.

Em matéria criminal, deve ser lembrado que no limiar da República ainda vigorava o sistema que atribuía ao júri o julgamento da maioria dos delitos, sendo previsto no art. 40 do Decreto n. 848 (BRASIL, 1890c) que o júri federal, presidido pelo juiz seccional, julgaria todos os crimes sujeitos à jurisdição federal. Assim, inicialmente, para todos os crimes havia uma fase de pronúncia e outra de julgamento, propriamente dito. A primeira fase era geralmente autuada como sumário crime e, havendo pronúncia, reautuada como processo crime. Normalmente, o processamento dos feitos, até a pronúncia, cabia aos juízes federais substitutos, embora não coubesse a eles a decisão de pronúncia ou impronúncia, salvo se no exercício da titularidade da vara federal, consoante dispunha o art. 18 da Lei n. 221/1894. (BRASIL, 1894).

Ao longo da Primeira República uma sucessão de leis foi retirando do júri federal a competência para julgamento de vários crimes, como o Decreto $n$. 4.381/1921 (BRASIL, 1921), que atribuiu ao juiz singular a análise de todos os crimes de falsificação de documentos de competência da Justiça Federal. Em 1923, com o Decreto n. 4.780 (BRASIL, 1923), a competência do júri federal passou a ser praticamente residual, em vista da enorme quantidade de exceções criadas nesse diploma legal, com a transferência do julgamento de vários crimes para o juiz singular.

De maneira genérica, o art. 60, letra $\mathbf{h}$, dizia caber aos juízes federais o processo e julgamento de "todas as questões de direito criminal e civil internacional", daí porque a Lei n. 2.416/1911 estabeleceu, em seu art. 14, §3º que "é sempre a Justiça Federal competente para conhecer dos crimes cometidos em território estrangeiro" (BRASIL, 1911), obviamente, nos casos em que as leis penais e processuais penais brasileiras admitissem a extraterritorialidade.

Algumas competências, no entanto, eram singulares, e só existiram no regime constitucional de 1891. A mais curiosa era aquela estabelecida no art. 60 , a, do texto constitucional, pelo qual competiria à Justiça Federal processar e julgar qualquer causa em que uma das partes fundasse a ação ou a defesa em dispositivo da Constituição Federal. Assim, teoricamente, bastaria que a parte alegasse violação a direito previsto expressamente no texto constitucional para que a demanda pudesse 
ser intentada na Justiça Federal. O STF teve que restringir o alcance da disposição constitucional, só admitindo que fosse atribuída à Justiça Federal se a ação ou defesa se baseasse direta e imediatamente em preceito constitucional, e não em lei ordinária também. (SANTOS, 1918, p. 618-622).

A Emenda Constitucional de 1926 (BRASIL, 1926) também retirou da alçada da Justiça Federal algumas das outras causas previstas no texto original da Constituição de 1891, como aquela entre cidadãos residentes em diferentes estados da Federação, quando divergentes as leis destes, uma clara tentativa de copiar preceito da Constituição norte-americana de 1787, mas que não tinha muito sentido no sistema brasileiro, uma vez que o direito substantivo remanesceu em sua maior parte na competência legislativa federal, diferentemente do que aconteceu nos Estados Unidos.

Em matéria eleitoral, deve ser lembrado que a criação da Justiça Eleitoral só ocorreu em 1932, de modo que todas as questões envolvendo eleições federais, até a criação daquela Justiça especializada, eram de competência dos juízes federais. Esses juízes, inclusive, tinham atribuições administrativas, na gestão das eleições, como o de compor as comissões revisoras do alistamento eleitoral, atribuições que foram sendo modificadas ao longo da Primeira República por sucessivas leis. Os crimes eleitorais, no entanto, independentemente da natureza do pleito, mesmo estaduais e municipais, sempre foram atribuídos à competência da Justiça Federal, conforme art. 54 da Lei n. 35/1892. (BRASIL, 1892).

\section{A JUSTIÇA FEDERAL NA CAPITAL DA REPÚBLICA E AS PARTICULARIDADES DO RIO DE JANEIRO COMO CENTRO POLÍTICO DO PAÍS}

Apresentada a instituição em seus delineamentos gerais, impende estabelecer, agora, quais as especificidades da Justiça Federal no Distrito Federal.

Em termos de estrutura, a Seção Judiciária da capital da República foi a primeira a ganhar uma segunda vara federal, já em 1904, e a única a ter três varas federais, a partir de 1924.

Como o Supremo Tribunal Federal ficava sediado no antigo município neutro do Rio de Janeiro, que passou a ser o Distrito Federal, era comum que os juízes federais com atuação na capital da República fossem convocados como ministros substitutos da Corte. O art. 13 do Regimento Interno do STF, de 1900, previa que na 
impossibilidade absoluta de se proceder a julgamento, pelo impedimento dos ministros, seriam chamados, sucessivamente, os juízes seccionais das seções mais próximas. Olympio de Sá e Albuquerque, por exemplo, magistrado com longa atuação nas seções do Rio de Janeiro e do Distrito Federal, atuou por todo o ano de 1935 como ministro substituto, até seu falecimento. (DOUTOR, 1936).

Essa proximidade não era garantia, por si só, de facilidades maiores no acesso à Corte Suprema. De 1890 a 1930 apenas cinco juízes federais lograram ser alçados à condição de ministro do STF, sendo que apenas dois eram juízes seccionais no Distrito Federal, Godofredo Xavier da Cunha e Antonio Joaquim Pires de Carvalho e Albuquerque. Posteriormente, mais três juízes federais que tiveram atuação na capital da República conseguiram chegar ao STF, Octávio Kelly, Cunha Mello e José de Castro Nunes. A título de comparação, em levantamento feito em 2020 (RODOR, p. 125-126), referente ao período de 1890 a 1930, foram identificados em 14 os desembargadores da Corte de Apelação da Justiça local do Distrito Federal que foram nomeados para o Supremo.

No que tange à identificação dos magistrados federais que atuaram na antiga Seção Judiciária do Distrito Federal, e o período de atuação de cada um, trata-se de um trabalho hercúleo. O Conselho da Justiça Federal - CJF, em 2000, intentou fazer o levantamento de todos os magistrados federais do período 1890-1990, lançando um Repertório Biográfico (BRASIL, 2000), mas essa obra tem muitas lacunas no que tange ao período de 1890-1937, já que escrita a partir de informações prestadas pelas próprias seções judiciárias, a maioria sem ter feito um trabalho completo e aprofundado de sua memória institucional. Esse trabalho, portanto, deve ser acrescido de outras fontes, como o lançado pelo Tribunal Regional Federal da 1르 Região, em 2010, visando o resgate da história da Justiça Federal. Mas foi apenas com o trabalho de Maria Panait (2018), que foi possível, ao menos quanto aos juízes seccionais e federais substitutos, relacionar os juízes e períodos de atuação em cada uma das seções judiciárias da Justiça Federal do primeiro ciclo.

No caso do Distrito Federal foram identificados os seguintes juízes seccionais e substitutos: a) Aureliano de Campos (seccional da vara única entre 1891-1897); b) Godofredo Xavier da Cunha (seccional da vara única entre 1898-1904 e seccional da $1^{\underline{a}}$ vara federal entre 1905-1910); c) Raul de Souza Martins (seccional da $1^{\underline{a}}$ vara federal entre 1911-1920); d) Olympio de Sá e Albuquerque (substituto da $2^{\mathrm{a}}$ vara 
federal entre 1908-1920 e seccional da 1a vara federal entre 1920-1935); e) Antonio J. Pires de C. e Albuquerque (seccional da $2^{\circ}$ vara federal entre 1905-1916; f) Octávio Kelly (seccional da $2^{\underline{a}}$ vara federal entre 1917-1934; g) Henrique Vaz Pinto Coelho (substituto da vara única entre 1896-1904 e da $1^{\text {a }}$ vara federal entre 19051926, e juiz seccional da $3^{a}$ vara federal entre 1926-1932); h) Aprígio Carlos Garcia de Amorim (substituto da 1a vara federal entre 1927-1932); i) Victor Manoel de Freitas (substituto da $2^{\underline{a}}$ vara federal entre 1922-1937); j) Waldemar da Silva Moreira (substituto da 3무 vara federal entre 1927-1937); k) Edgard Ribas Carneiro (substituto da 1a vara federal entre 1932-1937); .

Quanto aos juízes suplentes de substituto não se tem uma relação completa de seus nomes, ainda que na Seção Judiciária do Distrito Federal só houvesse três cargos por vara federal, diferentemente das seções judiciárias dos estados, em que, a partir de 1903, havia uma circunscrição com três suplentes para cada comarca existente na unidade federativa respectiva. $O$ exame da indexação dos feitos históricos tratados pela atual SJRJ, aliado os dados compilados por Panait, no entanto, nos indicam nomes de alguns desses magistrados, a saber: a) Aprígio Carlos Garcia de Amorim, que, como visto acima, também atuou como juiz federal substituto ( $1^{\circ}$ suplente de substituto da $1^{\text {a }}$ vara federal de 1916-1917); b) Omar Murgel Dutra (1ํ suplente de substituto da $1^{1 \stackrel{a}{ }}$ vara federal de 1928-1937); c) João Baptista Ferreira Pedreira (1ํㅗㄱ suplente de substituto da $2^{\underline{a}}$ vara federal de 1922-1937); d) Benjamin Antunes de Oliveira Filho (1ํㅡㄹ suplente de substituto da $1^{\underline{a}}$ vara federal de 1918-1928).

A atuação dos juízes federais no Distrito Federal, por vezes, era cercada de enorme pressão. Embora não tenha ocorrido nenhuma situação de extrema violência, como a que vitimou o juiz seccional do Piauí, Lucrécio Dantas Avelino, assassinado em 1927, supostamente a mando de um coronel do estado (O ASSASSINATO, 1928), ao menos um dos juízes seccionais da capital da República, Raul de Souza Martins, acabou tirando a própria vida em razão das críticas que recebeu em função da condução de um processo. (O SUICÍDIO, 1920).

No que tange à competência jurisdicional da Justiça Federal no Distrito Federal, não diferia muito, nem deveria, em relação àquela dos juízos seccionais dos estados. Algumas competências, no entanto, Ihe foram atribuídas com exclusividade. Com efeito, de acordo com o art. 17 da Lei n. 221/1894 (BRASIL, 1894), cabia 
exclusivamente ao juiz seccional do Distrito Federal processar e julgar as ações de nulidade de patentes.

A divisão da seção judiciária em mais de uma vara, logo em 1904, trouxe consequências de ordem prática, com a distribuição, por lei, de algumas funções com exclusividade para determinado juízo. A Lei n. 1.152/1904 (BRASIL, 1904a), inicialmente, determinava que as ações seriam distribuídas igualmente entre as varas federais. No entanto, uma série de leis posteriores mudou essa sistemática.

Em matéria eleitoral, por exemplo, atribuiu-se ao juízo da $2^{\mathrm{a}}$ vara federal várias competências administrativas, como o de organizar as seções eleitorais, distribuindo os eleitores entre elas (art. 9º $\S^{\circ}$, da Lei n. 3.208/1916) e o de organizar o Registro Geral dos Eleitores do Distrito Federal, recebendo dos juízes do alistamento as relações de eleitores alistados (art. 5ำ do Decreto n. 16.310/1924). (BRASIL, 1916b, 1924b).

No âmbito do Distrito Federal, as eleições locais resumiam-se à escolha dos intendentes do Conselho Municipal, que constituiria a atual câmara de vereadores, uma vez que o cargo de prefeito era de livre escolha do presidente da República. Essas eleições, inicialmente, eram organizadas por órgãos constituídos de componentes da Justiça local do Distrito Federal (Lei n. 939/1902) (BRASIL, 1902). Com o passar do tempo, no entanto, as atribuições foram sendo transferidas para os magistrados federais do Distrito Federal. Com efeito, com o Decreto n. 13.756/1919 (BRASIL 1919), por exemplo, a junta apuradora das eleições passou a ser a mesma das eleições federais (art. $7^{\circ}$ ).

Importante consignar que pelo Decreto n. 16.458/1921 (art. 60, parágrafo único), o juízo federal da $1^{\underline{a}}$ vara do Distrito Federal passou a ter competência exclusiva para processar e julgar os crimes referentes ao alistamento eleitoral, processos que se avolumaram em números crescentes a partir do momento em que o alistamento foi inteiramente judicializado com a Reforma Bueno Paiva, levada a efeito em 1916 pelas Leis ns. 3.139 e 3.208. (BRASIL, 1916a, 1916b)

No caso dos crimes políticos, propriamente ditos, ou seja, aqueles que atentavam contra o livre exercício dos poderes políticos, de conspiração e sedição, todos objeto de tipificação nos artigos 107 a 118 do Código Penal de 1890 (Decreto n.․ 847) (BRASIL, 1890b), a competência para o processamento e julgamento, nas seções judiciárias com mais de uma vara federal, caso do Distrito Federal, também 
passou a ser do juízo da primeira vara a partir do Decreto n. 16.561/1924. (BRASIL, 1924a).

Para uma análise do tipo de demanda que concretamente esteve submetida à Justiça Federal da capital da República, no período considerado neste artigo, é de vital importância o exame da base de indexação do acervo arquivístico da atual Seção Judiciária do Rio de Janeiro, fruto do projeto denominado "Organização do Acervo Arquivístico da Seção Judiciária do Rio de Janeiro: período 1890-1937", decorrente de contrato firmado entre o Tribunal Regional Federal da $2^{a}$ Região e a Fundação Euclides da Cunha, entidade de apoio da Universidade Federal Fluminense ${ }^{1}$.

O exame por amostragem desse rico acervo mostra que além de grande quantidade de execuções fiscais, o que era esperado, encontramos ações variadas, visando os mais distintos objetivos.

Em função da competência constitucionalmente atribuída à Justiça Federal para questões envolvendo direito marítimo e da navegação, eram comuns, por exemplo, ações de embargo ou ressarcimento por perdas e danos decorrentes de acidentes envolvendo embarcações, assim como vistorias por avarias. Uma demanda interessante foi a proposta, em 1898, pela companhia de navegação italiana Stefano Repetto (processo número 10 da indexação) visando o recebimento de prêmio, da União, pelo fato de ter transportado, no intervalo de um ano, mais de dez mil imigrantes, vindos espontaneamente para o Brasil, fora do regime de contratos.

A Lei n. 221/1894 (BRASIL, 1894), criou, em seu art. 13, uma ação especial, para as causas fundadas em lesão de direito individual por ato ou decisão de autoridade administrativa da União. Essa ação foi logo denominada de "ação sumária especial", e constituiu-se no verdadeiro antecedente histórico do nosso mandado de segurança. Sua adoção, no entanto, nunca alcançou o espectro de abrangência do habeas corpus, cuja ampla aplicação, durante a Primeira República, foi sufragada pela construção da chamada doutrina brasileira do habeas corpus. Ainda assim, encontramos no acervo histórico da SJRJ alguns interessantes exemplos de ações sumárias especiais julgadas procedentes ${ }^{2}$.

\footnotetext{
1 Essa base de dados está parcialmente disponível no sítio eletrônico (MEMÓRIA INSTITUCIONAL DA JUSTIÇA FEDERAL DA $2^{\mathrm{a}}$ REGIÃO, 2020), abrangendo cerca de um quarto da massa documental de processos compreendidos no primeiro ciclo de funcionamento da Justiça Federal.

${ }^{2} \mathrm{O}$ acervo indexado indica a existência de 722 ações sumárias especiais para o período 1890-1937, considerada apenas a parte tratada da massa documental.
} 
Em 1896, por exemplo, Luiz de Souza da Silveira, juiz de direito nomeado em 1880 para a Comarca do Riachão, no Maranhão, requereu e conseguiu a anulação de sua aposentadoria, decorrente do Decreto n. 2.056/1895 (BRASIL, 1895), do governo Floriano Peixoto, que aposentou os juízes do Império ainda não aproveitados nas novas estruturas judiciárias e que se encontravam em disponibilidade (processo 50 da indexação). Como a aposentadoria era com proventos proporcionais, ao contrário da disponibilidade de então, não havia interesse desses magistrados em serem aposentados.

Em outra ação sumária especial (processo 8535 da indexação), em 1908, Candido Mendes de Almeida, conhecido jurista e advogado brasileiro, requereu e conseguiu a anulação das decisões da comissão de alistamento eleitoral do Distrito Federal e da respectiva junta de recursos, que o haviam excluído da lista de leitores quando do novo alistamento preconizado pela reforma eleitoral decorrente da Lei Rosa e Silva (Lei n. 1.269/1904). (BRASIL, 1904b).

O mais comum, no entanto, era que essa ação fosse intentada por servidores públicos, incluindo militares, discutindo diferenças salariais, reclassificações, reintegrações ou anulação de atos da Administração Pública contra seus interesses, como aquela intentada em 1911 por João Frederico da Rocha, capitão do Exército, contra seu ato de reforma (processo 7088 da indexação).

Também muitas das ações ordinárias processadas na época em exame versavam sobre vantagens de servidores, incluindo magistrados, como a que foi apresentada por Diógenes Celso da Nóbrega, em 1922 (processo 18176 da indexação), nomeado juiz municipal da Comarca de Xapuri, no recém-criado território federal do Acre, e que alegava ter sido arbitrariamente demitido. Na ação, o autor requeria o reconhecimento de sua vitaliciedade com fundamento no Decreto $n$. 1.820/1907 (BRASIL, 1907b), tendo sido julgada procedente sua pretensão pelo juízo da primeira vara federal, com confirmação pelo STF.

Ainda em matéria cível, em vista das muitas intervenções urbanas feitas na cidade do Rio de Janeiro no início do séc. XX, principalmente as empreendidas pelo prefeito Pereira Passos, a partir de 1903, foi possível encontrar várias ações de desapropriação. Com efeito, a pesquisa da indexação retornou 632 resultados para o termo "desapropriação", conquanto alguns sejam de período posterior a 1937. São processos como o de número 12 da indexação, em que a União propôs, em face de 
Camilo Cresta e Cecília de Mattos Cresta, no ano de 1905, ação de desapropriação de prédio na Rua da Saúde, para proceder obras de melhoramentos no Porto do Rio de Janeiro. Em contrapartida, são encontradas ações em que o proprietário buscou defender seus direitos, como o processo n. 251 da indexação, em que João Nunes Santos Filho requereu ao juízo seccional, em 1904, a manutenção de posse de prédio na rua do Catete, ameaçado de demolição pela municipalidade após vistoria administrativa. $\mathrm{O}$ autor alegava que bastariam algumas reformas.

Em matéria criminal, muitas ações penais e inquéritos policiais versaram sobre crimes eleitorais, principalmente no alistamento, sonegação de tributos e falsificação, ideológica e de documentos. Moeda falsa e congêneres, crimes previstos nos artigos 239 a 244 do Código Penal de 1890 (BRASIL, 1890b), também eram relativamente comuns, pois encontramos 1241 resultados para a entrada "moeda falsa" na indexação da SJRJ. Na maioria das vezes, esses processos retratam situações prosaicas, em que a pessoa tentava repassar uma cédula falsa de dinheiro, caso do processo de n. 3092 da indexação, um sumário crime instaurado em 1909, em que Clotilde Cláudio, profissão costureira e prostituta, era investigada por tentar introduzir cédula falsa de $200 \$ 000$ em um café na Praça da República. A ausência de mecanismos de segurança das cédulas e o grande número de estampas em circulação, muitas ainda da época do Império, parece que facilitavam o cometimento desses delitos.

Superado o período de anormalidade institucional de aplicação do draconiano Decreto n. 85-A, de 23 de dezembro de 1889 (BRASIL, 1889), que submetia a uma comissão militar os crimes de conspiração contra a República e seu governo, a Justiça Federal assumiu a competência para o julgamento dos chamados crimes políticos, tanto os próprios, que hoje seriam o que denominamos de crimes contra a segurança nacional, quanto os impróprios, que eram os crimes eleitorais. $\mathrm{O}$ acervo histórico mostra a atuação da Justiça Federal no exame de procedimentos penais envolvendo tais crimes, como o que envolveu a apreensão de periódicos do jornal anarquista Spartacus em 1919, que estavam na posse de um tal Aquelino Cedon (processo 5839 da indexação), quanto de ações cíveis de pessoas que sofreram retaliações do governo por participação em movimentos considerados subversivos, como a ação sumária especial de Duarte Huet de Bacelar Pinto Guedes, ex-governador do Pará e um dos participantes do levante no vapor Júpiter durante a chamada Segunda Revolta 
da Armada (1892-1894), contestando o ato de sua reforma por acusação de crimes de sedição e conspiração (processo 16600 da indexação).

Outra ação penal interessante é a queixa-crime apresentada pelo expresidente da República Epitácio Pessoa, em 1924, contra o diretor do jornal Correio da Manhã, Mário Leite Rodrigues (processo 36541 da indexação), sob alegação de que sofria uma campanha caluniosa e injuriosa por parte do referido periódico.

Embora crimes de sangue nunca tenham sido comuns dentre os casos julgados no âmbito da Justiça Federal brasileira, foi possível registrar, muito em decorrência do tumultuado cenário político do Distrito Federal, alguns casos que envolveram violência e até homicídio. Caso emblemático foi o sumário crime de registro 15504 da indexação, retratando a invasão, em 31 de outubro de 1909, do saguão da Biblioteca Nacional, onde funcionava a $2^{\underline{a}}$ seção eleitoral da $4^{\underline{a}}$ pretoria, por ocasião das eleições de intendentes municipais, evento do qual resultou a morte do vigilante Marcelino Antonio de Oliveira. Caso ainda mais clamoroso, bem retratado nos periódicos da época, e que infelizmente não foi encontrado na parte do acervo histórico já indexada, foi o que resultou na morte de três pessoas, durante tiroteio ocorrido na $7^{a}$ seção da freguesia de Santa Cruz (ELEIÇÕES, 1909), e que envolvia políticos de renome da política local na época, como o coronel Honório dos Santos Pimentel e seu adversário político, a quem os homicidas seriam ligados, Octacílio Camará. Esses fatos reforçam o argumento de José Murilo de Carvalho (2019, p. 83) de que exercitar o voto no Rio de Janeiro era algo perigoso, tendo crescido o uso de capangas dos candidatos durante a Primeira República para garantir os resultados nos pleitos.

Um capítulo à parte diz respeito às ações de habeas corpus. Seu uso, para a proteção do direito de locomoção já era comum na década de 1890 e 1900, mas a partir da década de 1910 se percebe que estava amplamente difundida a utilização do instituto para a defesa de todo e qualquer direito individual que pudesse ser provado de plano, conforme preconizado por Rui Barbosa e sufragado pela jurisprudência do STF, na chamada doutrina brasileira do habeas corpus. Muitas dessas ações foram propostas diretamente no Supremo, pois eram de sua competência originária, mas outras tantas ingressaram na primeira instância da Justiça Federal. A indexação do acervo histórico da SJRJ indica 2.338 resultados para o argumento "habeas corpus". Numa análise por amostragem que fizemos de 220 
destas ações, verificamos ações desse tipo, afora aquelas sobre matéria penal, versando sobre temas variados, tais como: a) dispensa/isenção de alistamento militar; b) suspensão de multas administrativas; c) retorno ao serviço de servidores públicos suspensos de suas atividades; d) autorizações para ingresso em navios e edifícios públicos; e) concessão de ordem para prestação de exames na Escola Naval e outros.

Uma análise dos julgamentos históricos feitos pelo STF, conforme base de dados do sítio eletrônico da Corte $^{3}$, também indicam a existência de discussões jurídicas de alta relevância na Primeira República nos juízos federais do Distrito Federal, com posterior recurso para a Corte Suprema. É o caso do habeas corpus preventivo proposto em favor de Manoel Furtunato de Araújo Costa, reclamando da intimação recebida pelo inspetor sanitário para franquear a casa de sua residência, a fim de promover a desinfecção por motivo de febre amarela. Tratava-se de uma questão jurídica que estava relacionada com a chamada Revolta da Vacina, alegandose que estaria havendo violação à garantia constitucional da inviolabilidade domiciliar. A ordem foi negada pelo juízo da $2^{\mathrm{a}}$ vara federal do Distrito Federal, embora tenha sido dado provimento ao recurso pelo STF (RHC 2.244). Já no recurso em habeas corpus 2.793, julgado em 1909, a Corte manteve a sentença do juiz federal da $1^{\text {a }}$ vara, que havia negado a ordem impetrada por Thomaz Delfino dos Santos visando o reconhecimento da inconstitucionalidade do ato do Governo Nilo Peçanha que permitia ao prefeito do Distrito Federal governar sem a colaboração do Conselho Municipal, o qual se alegava não corretamente constituído. A matéria de fundo envolvia a questão de se reconhecer ou não ao Conselho Municipal a prerrogativa de proceder à verificação de poderes de seus membros, como era atribuído às casas legislativas do Congresso Nacional.

Sem dúvida, a população carioca era incomparavelmente mais urbanizada e instruída que a população em geral do restante do país. Isto, no entanto, não teria garantido, paradoxalmente, maior participação nos pleitos eleitorais, visto que em 1910, por exemplo, a participação eleitoral na capital federal era a metade da média geral do país (CARVALHO, 2019, p. 82). A cidadania, então, segundo José Murilo de Carvalho (2019, p. 137), era exercida por outros meios e mecanismos, mais facilmente verificável na reação dos consumidores de serviços públicos a certas medidas do governo. Um desses mecanismos poderia ser a busca da tutela jurisdicional. Com

\footnotetext{
${ }^{3}$ Encontrado em endereço eletrônico. (SUPREMO TRIBUNAL FEDERAL, 2020).
} 
efeito, para Gladys Sabina Ribeiro (2006, p. 162) as pessoas usaram a Justiça, desde o período imperial, para alargarem direitos.

Gladys Ribeiro, aliás, entende que o exercício da cidadania retratado nos processos judiciais do período não era apenas reativo, mas também participativo, em especial no caso do uso do habeas corpus, citando como exemplos, encontrados no acervo histórico da SJRJ, os inúmeros casos de ações intentadas por estrangeiros questionando a expulsão sumária do país autorizada pela Lei Gordo (Decreto $\mathrm{n}$. 1.641/1907), assim denominada em homenagem ao deputado paulista Adolfo Gordo, proponente da legislação. (RIBEIRO, 2006, p. 167).

Nessa linha, podemos citar como exemplo o processo n. 15047 da indexação, um habeas corpus proposto em 1907 pelo conhecido jurista Evaristo de Moraes em favor de Henrique Libram, cidadão de nacionalidade russa, que estaria preso na Casa de Detenção sob acusação de lenocínio, alegando, o impetrante, que o crime era uma invenção da polícia apenas para possibilitar a rápida expulsão do paciente, tido como anarquista. Essa ação foi julgada na $1^{\underline{a}}$ vara federal do Distrito Federal, tendo o juiz entendido não ser competente para impedir a aplicação da lei.

O fato do Judiciário da época não ter dado guarida a muitas das demandas propostas, mesmo os habeas corpus, acarretou a construção de tese contrária àquela defendida por Gladys Ribeiro. Com efeito, para outros estudiosos, o exercício da cidadania nas ações judiciais, durante a Primeira República, era bem mais restrito do que o preconizado por autores como Ribeiro, pois a facilidade do encaminhamento das demandas não necessariamente importou em efetivo resguardo de direitos daqueles de que dele se socorreram. (PINTO; CASTRO, 2019, p. 57).

A conclusão sobre qual a teoria mais correta parece ser possível somente a partir de um completo e profundo exame de todo acervo histórico da SJRJ, inclusive da parte que ainda não foi objeto de tratamento arquivístico.

De qualquer modo, o cenário político da capital do país era um pouco diferente daquele em vigor nos estados. O coronelismo típico do período até 1930, no caso da cidade do Rio de Janeiro, era contrabalançado com a influência na política local que o governo federal exercia. Com efeito, o modo de fazer política era distinto, pois, como defendido por Surama Conde Sá Pinto (2011, p. 69), para as elites políticas regionais, ali, não bastavam origem abastada e laços de parentesco, seja pelo perfil do eleitor 
carioca, seja pela sobreposição de instâncias políticas, o político do Distrito Federal tinha de cortejar a popularidade.

Essa forma diferente de distribuição do poder também tornava diferente o sistema de nomeações e de interferência do poder político sobre o Judiciário Federal da capital da República. Se para Koerner (2010, p. 172) o Judiciário da União participava da ordem política estabilizada com a política dos governadores, parece certo concluir que no caso do Distrito Federal as indicações dos magistrados federais atendiam muito mais o interesse direto do governo central do que qualquer concessão feita aos chefes políticos locais.

\section{CONCLUSÕES}

Como visto no presente artigo, a Justiça Federal brasileira foi organizada e criada antes mesmo da Constituição da República de 1891, conforme iniciativa do Governo Provisório, que resultou na edição do Decreto n. 848/1890. (BRASIL, 1890c).

No caso da cidade do Rio de Janeiro, então capital do país, foi criada uma seção judiciária específica, distinta daquela sediada em Niterói, e que respondia pelo restante do estado fluminense. A Seção Judiciária do então Distrito Federal foi a única que contou, durante o primeiro ciclo de funcionamento da Justiça Federal brasileira, que foi até 1937, com três varas federais instaladas, sendo possivelmente a que teve, tanto em números absolutos quanto em números proporcionais, a maior demanda do país à época.

O exame da indexação do acervo histórico da atual Seção Judiciária do Rio de Janeiro, mesmo se considerada apenas a parte tratada da massa documental correspondente, cerca de um quarto do total, nos mostrou uma variada gama de ações e demandas judiciais, muitas das quais acabando por serem decididas derradeiramente na segunda instância da Justiça Federal, o Supremo Tribunal Federal, que servia como tribunal de apelações da Justiça da União.

O acervo histórico da Justiça Federal no Rio de Janeiro conta importante capítulo da história da instituição, da organização política da capital da República e do próprio país, bem como nos mostra o tipo de tutela judicial normalmente buscada pelas partes, principalmente no que tange ao período da Primeira República, servindo como fundamental meio de pesquisa para dirimir a questão referente ao real alcance 
do exercício da cidadania pela população do Distrito Federal mediante a utilização dos meios e instrumentos de provocação da jurisdição para a efetivação de seus direitos, com especial destaque para o habeas corpus.

É crucial que seja retomada a continuidade do trabalho de tratamento do acervo histórico da SJRJ, iniciada em 2004, possibilitando que toda a comunidade tenha acesso a esse importante material, como fonte de pesquisa tanto da história da própria Justiça Federal, quanto das instituições políticas e administrativas que com ela interagiam ou que nela eram demandadas. Mais do que isso, a história dos processos conta inúmeras histórias individuais que mostram, em seu conjunto, a cultura e os hábitos vigentes, assim como os direitos que as pessoas visavam resguardar no período de 1890-1937.

\section{REFERÊNCIAS}

BARBOSA, Rui. A Constituição de 1891. In: BARBOSA, Rui. Obras completas de Rui Barbosa. Rio de Janeiro: Ministério da Educação e Saúde, 1943. Tomo XVII, v. 1.

BARBALHO, João. Constituição Federal Brasileira: comentários. Rio de Janeiro: F. Briguiet: Cia. Editores, 1924.

BASTOS, Aureliano Cândido Tavares. A província: estudo sobre a descentralização do Brasil. Rio de Janeiro: B. L. Garnier, 1870.

BASTOS, José Tavares. Organização Judiciária Federal. Rio de Janeiro: F. Briguiet Cia. Editores, 1913.

BASTOS, José Tavares. Reforma da Justiça Federal: estudo crítico da instituição, sua reorganização, projetos apresentados sobre a reforma no Parlamento e pareceres. Rio de Janeiro: Livraria Magalhães, 1912.

BRASIL. Anais do Congresso Constituinte da República. Janeiro: Imprensa Nacional, v. 2, 2. ed., 1926.

BRASIL. Anais da Assembleia Nacional Constituinte 1933/1934. Rio de Janeiro: Imprensa Nacional, v. 15, 1936.

BRASIL. Ato institucional n.o 2, de 27 de outubro 1965. Mantem a Constituição Federal de 1946, as Constituições Estaduais e respectivas Emendas, com as alterações introduzidas pelo Poder Constituinte originário da Revolução de 31.03.1964, e dá outras providências. Brasília, DF: Presidência da República, 1965. Disponível em: http://www.planalto.gov.br/ccivil_03/AIT/ait-02-65.htm. Acesso em: 29 jul. 2020. 
BRASIL. Conselho da Justiça Federal. Repertório Biográfico da Justiça Federal: 1890-1990. Brasília: CJF, 2000.

BRASIL. [Constituição (1891)]. Constituição da República dos Estados Unidos do Brasil de 1891. Rio de Janeiro, RJ: Presidência da República, 1891a. Disponível em: http://www.planalto.gov.br/ccivil_03/Constituicao/Constituicao91.htm. Acesso em: 29 jul. 2020.

BRASIL. [Constituição (1934)]. Constituição Da República Dos Estados Unidos Do Brasil. Rio de Janeiro, RJ: Presidência da República, 1934. Disponível em: http://www.planalto.gov.br/ccivil_03/constituicao/constituicao34.htm. Acesso em: 29 jul. 2020.

BRASIL. [Constituição (1937)]. Constituição Da República Dos Estados Unidos Do Brasil. Rio de Janeiro, RJ: Presidência da República, 1937. Disponível em: http://www.planalto.gov.br/ccivil_03/Constituicao/Constituicao37.htm. Acesso em: 29 jul. 2020.

BRASIL. [Constituição (1946)]. Constituição Dos Estados Unidos Do Brasil. Rio de Janeiro, RJ: Presidência da República, 1946. Disponível em: http://www.planalto.gov.br/ccivil_03/Constituicao/Constituicao46.htm. Acesso em: 29 jul. 2020.

BRASIL. [Constituição (1967)]. Constituição Da República Federativa Do Brasil De 1967.Brasília, DF: Presidência da República, 1967. Disponível em: http://www.planalto.gov.br/ccivil_03/constituicao/constituica067.htm. Acesso em: 29 jul. 2020.

BRASIL. Decreto no 13.756, de 10 de Setembro de 1919. Dá instrucções para e eleição de intendentes municipaes no Districto Federal. Rio de Janeiro: Presidência da República, 1919. Disponível em:

https://www2.camara.leg.br/legin/fed/decret/1910-1919/decreto-13756-10-setembro1919-502451-publicacaooriginal-1-pe.html. Acesso em: 29 jul. 2020.

BRASIL. Decreto n.o 1.152, de 7 de janeiro de 1904. Crêa na secção do Districto Federal mais uma vara de juiz federal e dá outras providencias. Diário Oficial da União, seção: 1, Rio de Janeiro, RJ: 9 jan. 1904a. Disponível em:

https://www2.camara.leg.br/legin/fed/decret/1900-1909/decreto-1152-7-janeiro-1904583467-publicacaooriginal-106286-pl.html. Acesso em: 29 jul. 2020.

BRASIL. Decreto n.o 1.420, de 21 de fevereiro de 1891. Amplia as attribuições dos substitutos dos juizes seccionaes e dá outras providencias. Rio de Janeiro, RJ: Presidência da República, 1891b. Disponível em: http://www.planalto.gov.br/ccivil_03/decreto/1851-1899/D1420A.htm. Acesso em: 29 jul. 2020.

BRASIL. Decreto n.o 16.310, de 8 de janeiro de 1924. Dá novas instrucções para as eleições federaes. Diário Oficial da União, seção: 1, Rio de Janeiro, RJ: 9 jan. 1924b. Disponível em: https://www2.camara.leg.br/legin/fed/decret/1920- 
1929/decreto-16310-8-janeiro-1924-521087-publicacaooriginal-1-pe.html. Acesso em: 29 jul. 2020.

BRASIL. Decreto n. 16.561, de 20 de agosto de 1924. Regulamenta o decreto $\mathrm{n}$. 4.848, de 13 de agosto de 1924, na parte em que dispõe sobre o processo e julgamento dos crimes contra a Constituição da Republica e fórma de seu Governo, contra o livre exercicio dos poderes politicos, de conspiração e de sedição. Diário Oficial da União, seção: 1, Rio de Janeiro, RJ: 27 ago. 1924a. Disponível em: https://www2.camara.leg.br/legin/fed/decret/1920-1929/decreto-16561-20-agosto1924-515645-republicacao-90165-pe.html. Acesso em: 29 jul. 2020.

BRASIL. Decreto n.o 1.820, de 19 de dezembro de 1907. Autoriza a expedição de novo regulamento para execução da lei n. 1181, de 25 de fevereiro de 1904. Diário Official, Rio de Janeiro, RJ: 21 dez. 1907b. Disponível em: https://www2.camara.leg.br/legin/fed/decret/1900-1909/decreto-1820-19-dezembro1907-582554-publicacaooriginal-105344-pl.html. Acesso em: 29 jul. 2020.

BRASIL. Decreto n.o 2.056, de 25 de julho de 1895. Aposenta, nos termos do art. 6ำ das disposições transitorias da Constituição Federal, os magistrados não aproveitados. Coleção de Leis do Brasil - 1895, v. 1. Disponível em:

https://www2.camara.leg.br/legin/fed/decret/1824-1899/decreto-2056-25-julho-1895538634-publicacaooriginal-43937-pe.html. Acesso em: 29 jul. 2020.

BRASIL. Decreto n.o 4.381, de 5 de dezembro de 1921. Autoriza o Poder Executivo a crear tres tribunaes regionaes no territorio nacional, fixa a alçada dos juizes federaes e dá outras providencias. Diário Oficial da União, seção: 1, Rio de Janeiro, RJ: 8 dez. 1921. Disponível em: https://www2.camara.leg.br/legin/fed/decret/19201929/decreto-4381-5-dezembro-1921-569428-publicacaooriginal-92676-pl.html. Acesso em: 29 jul. 2020.

BRASIL. Decreto n. 4.780 , de 27 de dezembro de 1923. Estabelece penas para os crimes de peculato, moeda falsa, falsificação de documentos, e dá outras providências. Diário Oficial da União, seção: 1, Rio de Janeiro, RJ: 30 dez. 1923. Disponível em: https://www2.camara.leg.br/legin/fed/decret/1920-1929/decreto-478027-dezembro-1923-568835-publicacaooriginal-92160-pl.html. Acesso em: 29 jul. 2020.

BRASIL. Decreto no 4.848, de 13 de agosto de 1924. Providencia sobre o processo e julgamento dos crimes de sedição. Rio de Janeiro: Presidência da República, 1924c.

BRASIL. Decreto n. 510, de 22 de junho de 1890. Publica a Constituição dos Estados Unidos do Brazil. Rio de Janeiro, RJ: Senado Federal, 1890a. Disponível em: http://legis.senado.leg.br/norma/388004/publicacao/15722625. Acesso em: 29 jul. 2020.

BRASIL. Decreto n.. 847, de 11 de outubro de 1890. Promulga o Codigo Penal. Coleção de Leis do Brasil - 1890b, v. 1. Disponível em: https://www2.camara.leg.br/legin/fed/decret/1824-1899/decreto-847-11-outubro1890-503086-publicacaooriginal-1-pe.html. Acesso em: 29 jul. 2020. 
BRASIL. Decreto n.o 848, de 11 de outubro de 1890. Organiza a Justiça Federal. Rio de Janeiro, RJ: Presidência da República, 1890c. Disponível em: http://www.planalto.gov.br/ccivil_03/decreto/1851-1899/D848.htm. Acesso em: 29 jul. 2020.

BRASIL. Decreto n. 85-A, de 23 de dezembro de 1889. Crêa uma commissão militar para o julgamento dos crimes de conspiração contra a Republica e seu governo, applicando-lhe as penas militares de sedição. Diário Oficial da União, seção: 1, Rio de Janeiro, RJ: 23 dez. 1889. Disponível em:

http://www.planalto.gov.br/ccivil_03/decreto/1851-1899/D0085-A.htm. Acesso em: 29 jul. 2020.

BRASIL. Decreto n.o 967, de 2 de janeiro de 1903. Crea o logar de consultor geral da Republica e dá outras providencias. Diário Oficial da União, seção: 1, Rio de Janeiro, RJ: 6 jan. 1903. Disponível em:

https://www2.camara.leg.br/legin/fed/decret/1900-1909/decreto-967-2-janeiro-1903584211-publicacaooriginal-106963-pl.html. Acesso em: 29 jul. 2020.

BRASIL. Emenda Constitucional de 3 de setembro de 1926. Emendas à Constituição Federal de 1891. Rio de Janeiro: Presidência do Senado, 1926. Disponível em: https://www2.camara.leg.br/legin/fed/emecon_sn/19201929/emendaconstitucional-37426-3-setembro-1926-564078-publicacaooriginal88097-pl.html. Acesso em: 29 jul. 2020.

BRASIL. Emenda Constitucional no 1, de 17 de outubro de 1969. Edita o novo texto da Constituição Federal de 24 de janeiro de 1967. Brasília, DF: Presidência da República, 1969. Disponível em:

http://www.planalto.gov.br/ccivil_03/Constituicao/Emendas/Emc_anterior1988/emc01 -69.htm. Acesso em: 29 jul. 2020.

BRASIL. Emenda constitucional no 7, de 13 de abril de 1977. Incorpora ao texto da Constituição Federal disposições relativas ao Poder Judiciário. Brasília, DF: Presidência da República, 1977. Disponível em:

http://www.planalto.gov.br/ccivil_03/constituicao/emendas/emc_anterior1988/emc0777.htm. Acesso em: 29 jul. 2020.

BRASIL. Lei $n .-1.269$, de 15 de novembro de 1904. Reforma a legislação eleitoral, e dá outras providencias. Diário Oficial da União, seção: 1, Rio de Janeiro, RJ: 18 nov. 1904b. Disponível em: https://www2.camara.leg.br/legin/fed/lei/1900-1909/lei1269-15-novembro-1904-584304-publicacaooriginal-107057-pl.html. Acesso em: 29 jul. 2020.

BRASIL. Lei $n .-221$, de 20 de novembro de 1894. Completa a organisação da Justiça Federal da Republica. Rio de Janeiro, RJ: Presidência da República,1894. Disponível em: http://www.planalto.gov.br/ccivil_03/leis/1851-1900/L0221-1894.htm. Acesso em: 29 jul. 2020.

BRASIL. Lei n.- 2.416, de 28 de junho de 1911. Regula a extradição de nacionaes e estrangeiros e o processo e julgamento dos mesmos, quando, fóra do paiz, 
perpetrarem algum dos crimes mencionados nesta lei. Diário Oficial da União, seção: 1, Rio de Janeiro, RJ: 2 jun. 1911. Disponível em:

https://www2.camara.leg.br/legin/fed/lei/1910-1919/lei-2416-28-junho-1911-579206publicacaooriginal-102088-pl.html. Acesso em: 29 jul. 2020.

BRASIL. Lei n.o 3.139, de 2 de agosto de 1916. Prescreve o modo por que deve ser feito o alistamento eleitoral e dá outras providencias. Diário Oficial da União, seção: 1, Rio de Janeiro, RJ: 13 ago. 1916a. Disponível em:

https://www2.camara.leg.br/legin/fed/lei/1910-1919/lei-3139-2-agosto-1916-574077republicacao-97309-pl.html. Acesso em: 29 jul. 2020.

BRASIL. Lei n.o 3.208, de 27 de dezembro de 1916. Regula o processo eleitoral e dá outras providencias. Diário Oficial da União, seção: 1, Rio de Janeiro, RJ: 29 dez. 1916b. Disponível em: https://www2.camara.leg.br/legin/fed/lei/1910-1919/lei-320827-dezembro-1916-572611-republicacao-98433-pl.html. Acesso em: 29 jul. 2020.

BRASIL. Lei no 35, de 26 de janeiro de 1892. Estabelece o processo para as eleições federais. Rio de Janeiro: Presidência, 1892. Disponível em: https://www2.camara.leg.br/legin/fed/lei/1824-1899/lei-35-26-janeiro-1892-541218publicacaooriginal-44167-pl.html. Acesso em: 29 jul. 2020.

BRASIL. Lei $n$. 9 939, de 29 de dezembro de 1902. Reorganisa o Districto Federal e dá outras providencias. Diário Oficial da União, seção: 1, Rio de Janeiro, RJ: 30 dez. 1902. Disponível em: https://www2.camara.leg.br/legin/fed/lei/1900-1909/lei-939-29dezembro-1902-585356-publicacaooriginal-108367-pl.html. Acesso em: 29 jul. 2020.

CARNEIRO, Levi. Do Judiciário Federal. Rio de Janeiro: Jacintho Ribeiro dos Santos, 1916.

CARVALHO, José Murilo de. Os bestializados: o Rio de Janeiro e a República que não foi. 4. ed. São Paulo: Companhia das Letras, 2019.

DOUTOR Olympio de Sá e Albuquerque: o falecimento do juiz da $1^{\text {a }}$ vara federal. Gazeta de Notícias, [S. I.], 1936. p. 18.

ELEIÇÕES municipais: pleito ensanguentado: três mortos e vários feridos. O Paiz, [S. I.], 1909. p. 3.

FREIRE, Felisbello. História constitucional da republica dos Estados Unidos do Brasil. Rio de Janeiro: Typ. Aldina, 1894. v.2.

FREITAS, Vladimir Passos de. Justiça Federal: histórico e evolução no Brasil. Curitiba: Juruá, 2003.

JUCOVSKY, Vera Lúcia Rocha Souza. Justiça Federal nos países que a adotam. Curitiba: Juruá, 2003.

KOERNER, Andrei. Judiciário e cidadania na Constituição da República brasileira (1841-1920). 2. ed. Curitiba: Juruá, 2010. 
LESSA, Pedro. Do Poder Judiciário. Rio de Janeiro: Livraria Francisco Alves, 1915.

MANIFESTO do partido republicano dirigido à nação em 1870. A Tribuna, Santos, 1939. Disponível em: http://www.novomilenio.inf.br/santos/h0103d.htm. Acesso em: 29 jul. 2020.

MEMÓRIA INSTITUCIONAL DA JUSTIÇA FEDERAL DA 2ª REGIÃO. CMI. Memória Institucional da Justiça Federal da 2a Região, Rio de Janeiro, 2020. Disponível em: https://www10.trf2.jus.br/memoria/. Acesso em: 28 jul. 2020.

NEQUETE, Lenine. O Poder Judiciário do Brasil a partir da independência. Atualização de Roberto Rosas. Brasília: Supremo Tribunal Federal, 2000. (v. II República)

OTÁVIO, Rodrigo. Constituições federaes: confronto da constituição federal dos $\mathrm{E}$. U. do Brasil, com as constituições da republica Argentina, dos E. U. da America e da Suissa acompanhado do texto completo das mesmas constituições. Rio de Janeiro: Livraria Clássica de Alves, 1897.

PANAIT, Maria da Conceição Cardoso. Justiça Federal (1890-1937): o processo de unificação pela estadualização. Curitiba: Apris, 2018.

PINTO, Surama Conde Sá. Só para iniciados... o jogo político na antiga capital federal. Rio de Janeiro: Mauad X: Faperj, 2011.

PINTO, Surama Conde Sá. CASTRO, Tatiana de Souza. O Poder Judiciário na Primeira República: revisitando algumas questões. Locus: Revista de história, Juiz de Fora, v. 25, n. 2, p. 37-58, 2019.

RIBEIRO, Gladys Sabina. O povo na rua e na Justiça, a construção da cidadania e luta por direitos: 1889-1930. In: SAMPAIO, Maria da Penha Franco; BRANCO, Maria do Socorro; LONGHI, Patrícia (Orgs.). Autos da Memória: a história brasileira no Arquivo da Justiça Federal. Rio de Janeiro, 2006.

RODOR, Ronald Kruger. O exercício da jurisdição eleitoral pela Justiça Federal, no Distrito Federal, durante a Primeira República. Dissertação (Mestrado em Direito Processual) - Universidade Federal do Espírito Santo, Centro de Ciências Jurídicas e Econômicas, Vitória, 2020.

ROURE, Agenor. A Constituinte Republicana. Brasília: Senado Federal, 1979. (Coleção Bernardo Pereira de Vasconcelos - série estudos jurídicos, v. 17).

SALLES, M. Ferraz de Campos. Exposição de motivos. In: BRASIL. Decreto n.o 848, de 11 de outubro de 1890. Organiza a Justiça Federal. Rio de Janeiro, RJ: Presidência da República, 1890. Disponível em:

http://www.planalto.gov.br/ccivil_03/decreto/1851-1899/D848.htm. Acesso em: 29 jul. 2020.

SANTOS, Carlos Maximiliano Pereira dos, 1873-1960. Commentarios à constituição brasileira. Rio de Janeiro: Jacinhto Ribeiro, 1918. 
SUPREMO TRIBUNAL FEDERAL. Julgamentos históricos. STF, Brasília, DF, 2020. Disponível em:

http://www.stf.jus.br/portal/cms/verTexto.asp?servico=sobreStfConhecaStfJulgament oHistorico\&pagina=STFlista1. Acesso em: 28 jul. 2020.

O ASSASSINATO do juiz federal do Piahuy. Jornal do Comércio, [S. I.], 1928. p. 2.

O SUICÍDIO de um juiz: o Dr. Raul Martins pôs termo à existência ingerindo lysol. Gazeta de Notícias, [S. I.], 1920. p. 1. Disponível em:

http://memoria.bn.br/pdf/103730/per103730_1920_00323.pdf. Acesso em: 19 jul. 2020. 